\title{
APIE FILOSOFINES DAILÉS TERAPIJOS IŠTAKAS IR TAIKYMO GALIMYBES
}

\section{The Philosophical Origin of Art Therapy and its Practical Application}

\author{
SUMMARY
}

The article reviews the philosophical and psychological origins of Art Therapy and its practical application possibilities. A special focus is given to the influence of the views based on philosophical and psychological ideas of art therapy functions, methods and practical significance. The article aims to highlight the positive benefits of the adoption of art therapy techniques and their effects on health of a human soul and body as well as a self-cognition. The focus is on a creative process, which is considered to be one of the most important elements of art therapy. The advantages of art therapy, such as a self-expression through colours, the personality in self-creation, the education of the personal creativeness and spirituality, are concisely presented in the paper.

\section{SANTRAUKA}

Straipsnyje apžvelgiamos dailès terapijos filosofinès ir psichologinės ištakos, pagrindinès nuostatos ir jų taikymo praktinès galimybės. Nagrinėjamos dailès terapijos pamatinių teorinių nuostatų sąsajos su neklasikine, gyvenimo filosofija ir įvairiomis psichopatologinėmis bei psichoanalitinėmis koncepcijomis. Ypatingas dèmesys skiriamas dèl filosofijos ir psichologijos idèjų įtakos susiformavusių požiūrių i dailès terapijos funkcijas, metodus ir praktinę reikšmę analizei. Straipsnyje siekiama išryškinti dailès terapijos metodų pritaikymo naudą ir poveiki žmogaus vidinei būsenai, jo fizinei ir dvasinei sveikatai bei savęs pažinimui. Analizuojant dabartinès dailès terapijos ypatumus, susitelkiama į meninès kūrybos procesą, kuris traktuojamas kaip vienas svarbiausių dailès terapijos dėmenų.

$\mathrm{K}^{\mathrm{a}}$ aip jau buvo minèta, nors esama skirtingu ir net prieštaringu dailès terapijos metodu ir jos vykdymo formų, tačiau visur pagrindinis demesys krypsta i kūrybos procesą ir žmogų. Kūrybinis procesas yra vienas svarbiausių dailès 
terapijos dėmenų. Todèl glaustai panagrinèkime pati tapybos procesa, kuo jis yra svarbus? Dailès terapija remiasi prielaida, kad būtent terapijos proceso metu žmoguje ivvyksta pokyčiai, atsipalaidavimas, susitaikymas, išgijimas. Pažymètina, kad visi „dailès terapijos metodai grindžiami prielaida, kad kiekvienas žmogus, mokantis ar nemokantis piešti, turi igimtą (slaptą) gebejjimą savo emocijas, jausmus, būsenas išreikšti atitinkama spalva ir, pasirinkęs atitinkamas priemones bei technika, gali perteikti savo išgyvenimus. Tai ir yra vadinama kūrybiniu procesu. Čia labai svarbi dalyvio emocinè atmintis, pagrindinis savireguliacijos ir tobulejjimo šaltinis, atskleidžiantis vidines (prigimtines) galias savęs pažinimui, kūrybai, savigydai“ ${ }^{20}$.

Todèl dailès terapijos seansų metu siekiama ugdyti asmenybès individualumą ir laisvumą. Laisvė ir intuityvumus yra esminiai terapinio-kūrybinio proceso bruožai, nes dailès terapijos procese darbai kuriami natūraliai, be proto kontrolès, kas padeda išreikšti pasąmoninius išgyvenimus per simbolius ir vizualines formas. Todèl visi dailès terapeutai sutartinai tvirtina, kad norint dalyvauti meno terapijoje jokie piešimo igūūžiai nereikalingi. Kas yra išties būtina šiame kūrybiniame procese - tai paties žmogaus pastangos, noras atsiverti. Intuityviai atliekamas kūrybinis procesas - vienas iš svarbių dailès terapijos metodų, leidžiančių panirti i savo vidini pasauli, o gautas meno kūrinys yra lyg vidinio dvasinio pasaulio atspindys, padedantis žmogui geriau pažinti save. Čia atsiskleidžia terapinès ir diagnostinès dailès terapijos prielaidos. Dailès terapeutai, pasitelkda- mi vaizduojamosios raiškos „atpažinimo" būdus, kūrybinius procesus gali aiškinti psichologijos mokslo terminija ${ }^{21}$.

Šiame kontekste meninè kūrybinès išraiškos būdai (spalvos, linijos, formos) tampa nustatymo priemone, leidžiančia pamatyti žmogaus viduje slypinčias patologijos grèsmes, poelgių motyvus ir psichologines būsenas. Tačiau tam būtina sukurti ryši tarp kliento, terapeuto ir meno produkto. Terapeutas konsultuoja ir padeda žmogui tarsi pažvelgti i save per atstuma, surasti reikiamus problemų sprendimo būdus, padeda atkurti pažeistą bendravimo su artimaisiais ar socialine aplinka santyki. Jis, anot dailès terapeutès Dapkutès, iškyla kaip kliento dialogo su vaizduojamąja produkcija tarpininkas ${ }^{22}$. Vis dèlto, Šapokos teigimu, apskritai vertinant, tokios diagnostinès prielaidos gali būti sąlyginès ir nevienareikšmiškos, bet kokia dailès terapijos diagnostine išvada tuo pat metu yra ir konstruktyvi, ir receptyvi, kitaip tariant, ji visada yra tik daugiau ar mažiau argumentuotas spejjimas ${ }^{23}$.

Kitas svarbus dailès terapijos dėmuo yra saviraiška spalvomis. Dailès terapija remiasi kūrybine išraiška kaip galimybe išsisakyti. Menas yra universaliausia kalba. Ir dažnai neverbali kalba yra ittaigesnė ir stipresnè už bet kokius garsiai pasakytus žodžius. Kaip taikliai pastebejjo Ludwigas Wittgensteinas savo analitinèje filosofijoje, pasakyti žodžiai dažnai negali tiksliai ịvardyti tikrovès, todèl žmonès tarpusavyje nesusikalba, kyla ìvairūs nesutarimai ir nesusipratimai ${ }^{24}$. Iš tiesų kartais mūsų išgyvenimai per daug sudètingi ir painūs, kad galètume juos suprantamai išreikšti žodžiais sau 
ir kitiems. Spalvos - tai netiesioginè komunikacijos priemonè, kuri leidžia kalbèti laisvai ir nevaržomai.

Ivairūs spalvų deriniai ir charakteristika - tai tarsi vizualūs pranešimai, kuriuose slypi žinia apie jausmus ir kurie leidžia pamatyti savo silpnąsias bei stipriąsias puses. Spalvos kaip saviraiškos priemonė padeda iškelti i viršų - ant piešimo lapo - tai, kas buvo giliai užslèpta žmogaus širdyje, kas ji slègè, neramino. Dèl to žmogus patiria dvasinị apsivalyma, išsilaisvinimą. Pastebima, kad po tokių dailès terapijos praktinių užsièmimų, kai asmuo išreiškia savo vidinị patyrimą vaizduodamas (piešdamas), jis ne tik geriau išmoksta pažinti savo mintis, bet sustiprejja gebejimas valdyti savo jausmus, išauga tolerancija, savigarba sau ir kitiems žmonėms. Pastaraisiais metais atliktais tyrimais izrodyta, jog kūryba pozityviai stimuliuoja psichinę ir fizinę žmogaus sveikatą. Tokius gautus teigiamus rezultatus ir konstruktyvias pastabas plačiai aprašo JAV nuo 1983 m. leidžiamas periodinis leidinys ${ }^{25}$.

Taigi, kaip buvo mineta, meno terapijos ištakos susijusios su psichoterapija, čia glūdi jos pirminès prielaidos. Todèl glaustai apžvelkime, kokie yra jų sąlyčio taškai. Dailès terapeutè Margaret Naumburg, kurios vardas siejamas su dailès terapijos užuomazgomis JAV, sekdama psichoanalizès idejomis, teigia, jog vaizduojamoji kūryba sujungia nesąmoningają ir sąmoningają sferas per archajiškus simbolius, kurių pats autorius nepajègus iškoduoti ar interpretuoti ${ }^{26}$. Remiantis psichoanalizès pradininko Freudo nuostatomis, galima sakyti, kad kiekvienu kūriniu per tam tikrus simbolius autorius tarsi „išlieja“ savo vidiniame pasaulyje gimusius vaizdinius, slapčiausius siekimus ir potraukius. Meno kūriniuose glūdi prisiminimai, nesąmoningai nuo paties autoriaus paslèpta tikroji jo asmenybès charakterio pusè. Padèti žmogui pažinti save, atverti jam savo sielos gelmines versmes ir šitaip ji apsaugoti nuo savęs paties, padèti jam igyti drąsos išsilaisvinti ir ittvirtinti save - ši uždavini sau iškelia Freudas ${ }^{27}$. Arba, kitaip tariant, leisti nesąmoningam turiniui surasti kelią i sąmonę ir išvaduoti individą nuo įkalinimo savo kompleksuose ir ribose. Tam tikslui pasiekti svarbu surasti tą lemiamą taška, kur prasidèjo skausmingas suklupimas, žmogaus psichikos sužeidimas.

Jau Schopenhaueris manè, ,jog psichinius sukrètimus visiškai išgydyti būtų galima tada, jeigu pasisektų priglusti prie to vidinio gyvenimo taško, kur buvo patirtas lemiamas sukrètimas: norint sužinoti, kodèl žiedas vysta, reikia ištirti augalą iki pat šaknų ${ }^{\prime 28}$. Tad Freudas, kaip ir Schopenhaueris bei kiti iracionalistai, meninę kūrybą sieja su žmogaus būties tragizmu, kančia, troškimu atitrūkti, išsilaisvinti, palaikyti psichinę pusiausvyrą. Meninè kūryba yra galimybè atitolti nuo grèsmingos realybès, žiaurios tikrovès, kūryba - tai svajonių, fantazijų, užslèptų skausmingų emocinių išgyvenimų, aistrų, troškimų išraiška (sublimacija), iš kurios gimsta meno kūriniai. Abiejų pastarujų mąstytojų koncepcijose „nesąmoningas pradas yra centras, šerdis, iš kur plaukia visi žmogaus gyvenimo, psichinès ir kūrybinès veiklos gelminiai impulsai, nuolat balan- 
suojama tarp teigiamų ir neigiamų, genialumo ir beprotybės, pozityvių kūrybinių ir destruktyvių impulsų “29.

Šis nesąmoningumo pradas, stipriai veikiantis asmenybès elgesi, charakteri, būda, yra dailès terapijos branduolys. Šiame kontekste atsiskleidžia, kaip psichoanalizès pradininko Freudo mintys nulèmè meno terapijos problemų lauka, metodus ir tikslingumą bei konceptualias prielaidas, kad ,giluminès, nesuvoktos mintys ir jausmai dažniausiai išreiškiami ne žodžiais, o vaizdiniais ir simboliais. Meno priemonėmis išreikšti vaizdiniai atspindi visus pasąmoningus procesus, tarp ju baimes, vidinius konfliktus ${ }^{\text {“30 }}$. Freudo sekèjo Jungo analitinè psichologijos teorija ${ }^{31}$ dar labiau sustiprino prielaidas, kad kliento tapybos kūrinys slepia kur kas gilesni pasąmonini simbolini lygmeni. Tad dailès terapija, savo ištakas radusi kaip psichoterapijos pagalbinè priemonè, suteikia galimybę žmogui nusimesti kaukes, i̇veikti asmenybę griaunančias destruktyvias jègas, panirus ì savianalizę atrasti praeityje išgyventas nesėkmes. Kaip, pavyzdžiui, dailès terapijos metu žmogus gali bent jau vaizduoteje atkurti tai, kas yra prarasta, arba buvę praeityje, gali atkurti nemalonią trikdančią scena, nelaimingą atsitikimą arba sunkias akimirkas. Jis gali nupiešti ta, kuris mirè, ir pasakyti jam tai, ko niekad neprisiruošè pasakyti, arba atsiimti žodžius, kuriuos gailisi pasakęs. Tokiu būdu atvaizduojant praeityje buvusius ivykius, sukyla su jais susijusios emocijos, o šias emocijas išreiškus, galima pajusti palengvejjimą ${ }^{32}$.

Arnoldas Hauseris, lygindamas psichoanalizę su ịvairiomis estetikos ir me- no filosofijos srovėmis, ją traktuoja kaip vieną iš pirmujju, kuri taip giliai sugebèjo atskleisti ir paaiškinti paslèptus kūrybos šaltinius. Anot jo, psichoanalizè interpretuoja meno kūrini kaip asmenini dokumentą ir paaiškina menini stilių kaip ypatingu psichologinių polinkių išraišką ${ }^{33}$. Tad remiantis šiomis izžvalgomis galima teigti, kad meninè kūryba dailès terapijos metu leidžia išreikšti sunkiai išreiškiamas, užblokuotas pasąmonines emocijas ir atlieka tarsi perkèlimo, išsisakymo, išsivalymo funkciją ir tampa pozityviu žmogaus vidinès ir išorinès tikrovès koordinavimu.

Be to, dailès terapija, kaip viena iš menų terapijos rūšių, yra taikytina ne tik atliekant reabilitacinę ar diagnostinę funkcijas, bet gali būti siejama su natūraliu poreikiu išlaisvinti žmoguje glūdintị kūrybiškumą; tai yra sustiprinti individo kūrybinę potenciją, norą tobulèti, atrasti naujas, dar neatskleistas savo asmenybès galimybes. Kaip pabrèžia gyvenimo filosofas Bergsonas savo programiniame veikale Kūrybinè evoliucija, asmenybejje slypi didelè saviraiškos ir galimybių programa. Žmogaus asmenybè, gilusis Aš, kaip ir gyvenimas, nepaliaujamai auga, dideja, bręsta, nuolat kinta. Žmoguje glūdinti intuicija yra tas šauklys, kviečiantis ir raginantis kurti. Būtent menas, anot prancūzų filosofo, yra tobuliausia igimto žmogaus sugebèjimo kurti forma. Kūryba yra žmogaus savastis - mumyse slypintis gyvybinis polèkis élan vital yra siekis kuo plačiau realizuoti duotas galimybes. Taigi žmogaus egzistencijos esmę lemia intuicija, kuri padeda atitrūkti nuo daiktiškojo pasaulio, pajusti savo vidines gelmes ir 
pakilti ì dvasinę sritị. Intuicijos dèka atgyja gyvybinis polèkis, kuris intelekte yra sustingęs ${ }^{34}$. Taigi menų terapijos praktikose atsispindi gyvenimo filosofijos idejjos ir prielaidos, kad intuityvi meninè kūryba tiesiogiai veikia prigimtini žmogaus kūrybinguma, skatina asmenybès savikūrą ir augimą. Dar daugiau, menas padeda atskleisti žmogaus asmenybės unikaluma, nepakartojamumą ir individualumą.

Ir pabaigai, nagrinèjant meninès saviraiškos poveiki žmogui, verta trumpai aptarti dvasinguma, kuris yra vienas iš reikšmingiausių dailès terapijos sesiju aspektų. Anot Kučinskienès, dvasingumas plačiąja prasme ir dailès terapija yra tarpusavyje susiję fenomenai. „Galime drąsiai teigti, kad tarp jų egzistuoja tarpusavio ryšys. <..> Tiek dvasingumas, tiek dailès terapija gali būti apibūdinami per patiriamą santyki su Dievu, su pačiu savimi ir kitais. " 35 Dabartinis žmogus susiduria su daugeliu sunkių iššūkių ir išmėginimų - atmetamos pamatinès krikščioniškos dorybès, slegia gyvenimo beprasmybè, ištinka vertybinè krizė, apima dvasinis skurdas, vienišumo jausmas, kyla bendravimo problemų. Dabartinejje industrinèje technologijų visuomenèje, kur nepaliaujamas tempas, triukšmas, vis labiau trūksta vidinio susikaupimo, dvasingumo, dèmesio sau.

Daugelis giliai tikinčių žmonių savyje jaučia ilgesi amžinybės - Dievo, to, kas tikra, amžina, nesikeičia, kuris yra Meilè. Juk vienas iš svarbiausių žmogaus prigimtinių troškimu yra jaustis vertingam, mylèti ir būti mylimam. Todèl dailès terapija gali būti orientuojama ị tokias amžinas vertybes kaip tikejjimas, viltis, meilè, dèkingumas. Kučinskienè, analizuodama dvasingumo ir dailès terapijos santyki, remiasi Catherine Moon, kuri palygino dailę su malda. Pastarosios teigimu, „dalydamiesi savo skausmu ir viltimi dailès terapijos sesijose, jų dalyviai tampa eucharistine bendruomene, atvira susitikimui su Dievu, paslaptimi, jèga, kuri yra stipresnè už žmogų. Labai žmogiška vengti skausmo, pažeminimo, kančios, tačiau kūryba, gimstanti išgyvenant šiuos jausmus, yra šuolis tikejjimo link. "36 Meno terapeutè Moon į savo darbą žvelgè trimis svarbiausiais krikščioniškos teologijos aspektais: per malda, sakramentus ir malonę. Theresa Crooks knygoje Dvasingumas, kūrybiškumas, tapatumas ir dailes terapija pristato daug meno terapeutu, kurių krikščioniškas tikejjimas i Dievą turejjo teigiamą ir efektyvų poveiki jų darbui su klientais. Crooks dalijasi ižvalgomis, kad terapeuto gilus tikèjimas tarsi atveria kelią Dievui veikti per ji ir padèti žmonėms. Kita svarbi Crooks tyrinejjimų nuostata - meno terapija gali padèti atrasti ir išgyventi Dievą kaip Kūrëja, ir ši perspektyva padidina gydomąą meno galią ${ }^{37}$.

Taigi pasitelkdami kūryba, meninę saviraišką ir dailès terapijos metodus, galime ne tik atkurti savo emocinę ir dvasinę pusiausvyra, bet, svarbiausia, atrasti santyki su Dievu; priimant Dievo meilę išmokti mylèti save, gyvenimą ir kitus. Tad dailès terapijos sesiju metu žmogui padedama atkurti ryši ne tik su savimi ir kitais, bet, svarbiausia, pajausti ryši ir su Aukščiausiuoju Kūrèju, kuris dovanoja žmogaus gyvenimui pilnatvę ir egzistencinę prasmę. 


\section{IŠVADOS}

Glaustai aptarę kai kuriuos svarbesnius dailès terapijos ideju genezès aspektus, galime konstatuoti, kad neklasikinè ir gyvenimo filosofija bei iqvairios ankstyvosios psichologinès teorijos, apmąstančios meninès raiškos įtaką asmenybei, nesąmoningumo sferą bei įvairius psichopatologinius procesus, turèjo didžiuli poveiki ịvairiu psichoterapijos, tarp ju ir dailès terapijos, konceptualių nuostatu raidai. Dabartine iš ivvairiu filosofiniu ideju ir psichoterapijos formu išsirutuliojusi dailès terapija nèra statiška, o sudètinga ir sparčiai besikeičianti dabartinès humanistikos sritis, kuri turi plačias praktinio pritaikymo galimybes, nuolat tobuleja jos metodai ir darbo priemonès. Taigi dailès terapija nèra vien siauras ir uždaras specializacijos dalykas, bet tarpdalykinè kompleksinè disciplina ir integrali sistema, kuri paremta vizualinio meno kūrybiniu procesu, psichologijos ir psichoterapijos sinteze jungianti i̇varius, dažnai net prieštaringus praktinius veiklos metodus ir medicininius vertinimus. Ji plačiai taikoma medicinos, švietimo ir socialinèse įstaigose.

Kita vertus, dabartinè dailès terapija kartu yra savita asmenybès ugdymo

\section{Literatūra ir nuorodos}

20 Marija Mendelè-Leliuginè, Socialiai atsakingos asmenybès ugdymo modelis. Metodinis leidinys. Vilnius: Justitia, 2012, p. 100.

21 Pgl. Людмила Лебедева, Практика арт-терапии: подходы, диагностика, система занятий. Санкт Петербург: Речь, 2007, с. 40. priemonè, arba psichoterapijos forma, orientuota i kiekvieno žmogaus prigimtiniu galių išsklaida, pabrèžiant kūrybinio proceso intuityvuma, kuris yra svarbiausias dailès terapijos dèmuo. Kreipdamasi i giliausius dvasinius asmenybės sluoksnius, jautriausius užslëptus išgyvenimus, dailès terapija siekia padèti asmeniui harmonizuoti santykius su išoriniu pasauliu ir pačiu savimi. Todèl aktyvus asmens įtraukimas i meninès kūrybos ar meno kūrinių suvokimo procesą tampa svarbia pagalbine priemone asmenybės ugdymui, terapijai ir reabilitacijai. Dailès terapija siekia padèti save suprasti, pajausti, išreikšti. Todèl dailès kūrinys traktuojamas kaip vidinio pasaulio atspindys, kuris atskleidžia žmogaus išgyvenimus ir vertybines nuostatas. Iš čia kyla ir pagrindinis paties dailès terapijos proceso tikslas - padèti žmogui sužinoti ir priimti tiesą apie save, susigaudyti savo jausmuose ir mintyse, atkurti dvasinę ir emocinę pusiausvyrą, suteikti jègų nugalint sunkumus, lavinti kūrybinius igūdžius ir ugdyti dvasingumą. Tad dailès terapijos sesijų metų žmogui padedama atkurti ryší ne tik su savi$\mathrm{mi}$ ir kitais, bet, svarbiausia, pajausti ryši ir su Aukščiausiuoju Kūrèju.

22 Aldona Dapkutè, Kalba be žodžiu. Vilnius: Rafaelis, 2003, p. 15.

23 Kęstutis Šapoka, Dailès terapija; ištakos ir įtakos. Dailès terapijos diagnostinė funkcija: nupiešk savo sielą. Kultūros barai 12, 2011, Vilnius: Všı „Kultūros barų“ leidykla, p. 73-79. 
${ }^{24}$ Pgl. Ludvig Wittgenstein, Filosofiniai tyrinèjimai. Rinktiniai raštai. Vilnius: Mintis, 1995.

${ }^{25}$ Art Therapy. Journal of the American Art Therapy Association. Volume 33, Issue 1/2, (2016) http:// www.tandfonline.com/toc/uart20/current

${ }^{26}$ Pgl. Waller Diane, Art Therapy in United Kingtom: Some Theoretical and Contextual Consideration. International Journal of Art Therapy, No. 2. London: British Association of Art Therapists, 1998, p. 13.

27 Pgl. Erichas Fromas, Psichoanalize ir religija. Vilnius: Mintis, 1981.

${ }^{28}$ Stefan Zweig, Apie Zigmunda Froida. Portretas. Iš vokiečiu k. vertè Elena Zambacevičiūtè. Vilnius: Vyturys, 1999, p. 85.

29 Antanas Andrijauskas, Freudo psichoanalitinis posūkis. Kelias nuo metafizikos į metapsichologiją. Neklasikinés ir postmodernistinés filosofijos metamorfozés. Vilnius: Meno rinkos agentūra, 2010, p. 324.

30 Savęs pažinimo ugdymo modelis panaudojant dailès terapiją. Metodinis leidinys. Vilnius: Všt Asmenybès ugdymo institutas "Rafaelis“, 2012, p. 263.

31 Jung Karl Gustav, Psichoanalize ir filosofija. Iš vokiečių k. vertė Zigmantas Ardickas. Vilnius: Pradai, 1999.

32 Dalley Tessa, John Birtchnell, Meno terapija kaip psichoterapijos forma. Daile kaip terapija: dailes taikymo gydymui iquadas. Vilnius: Apostrofa, 2004, p. 66.

33 Arnold Hauser, The Philosophy of Art History. London: Vintage Book, 1959, p. 109.

34 Pgl. Henri Bergson, Kürybine evoliucija. Iš prancūzų k. vertė Petras Račius. Vilnius: Margi raštai, 2004.

35 Rasa Kučinskienė, Dvasingumo aspektas dailès terapiju metu. Meno terapija: realijos ir perspektyvos Tarptautinès mokslinès konferencijos medžiaga. Šiauliai: Všț Šiaulių universiteto leidykla, 2013, p. 50.

36 Rasa Kučinskienė, Dvasingumo aspektas dailès terapiju metu. Meno terapija: realijos ir perspektyvos. Tarptautinès mokslinès konferencijos medžiaga. Šiauliai: Všt Šiaulių universiteto leidykla, 2013, p. 49.

37 Theresa Crooks, Spirituality, Creativity, Identity, and Art Therapy. 2013, prieiga per internetą: $<$ http://digitalcommons.lmu.edu/cgi/viewcontent.cgi?article $=1123 \&$ context $=$ etd $>$. 